\title{
NOTES ON THE IMPLANTATION OF QUALITY AND PRODUCTIVITY PROGRAMMES IN SECTORS OF BRAZILIAN INDUSTRY
}

\section{Roberto Ruas}

\section{INTRODUCTION}

The profound changes taking place in international competition in manufactured goods have, albeit tardily, begun to have an impact on Brazilian industry. The current interest in and attraction to everything related to improvements in quality and productivity are starting to look like 'competitiveness mania'. In spite of many problems, the changes now taking place have led to considerable improvements in measures of company performance, particularly in the areas of quality and productivity (Lima 1989; Fleury and Humphrey 1992). This upsurge of interest in quality and productivity is seen clearly at company level, but it has more global forces driving it forward.

In the first place, the crisis of the Brazilian economy has cut back the domestic market so much that companies aiming to maintain sales have had to look to export markets. Industrial production has fallen sharply in recent years (see Table 1). This is the context in which firms have begun to be concerned about the gap between domestic and international standards of quality and productivity and about all that this implies for costs, prices, product characteristics and delivery dates. Table 1: Industrial Production in Brazil, Per
Cent Change on Previous Year

\begin{tabular}{|lc|}
\hline & $\%$ \\
Year & \\
1987 & +0.9 \\
1988 & -3.2 \\
1989 & +2.9 \\
1990 & -8.9 \\
1991 & -0.5 \\
1992 (1st half) & -3.1 \\
& \\
\hline Source: Rio de Janeiro, IBGE.
\end{tabular}

A second factor driving companies forward is the liberalization of the domestic market by means of progressive reductions in import tariffs, which has resulted in a growing internationalization of competitiveness in some sectors of the domestic market. Until recently, the protective barriers erected by the import-substitution model created internal competitive conditions which were largely independent of those prevailing in external markets. Therefore, the prospect of the internationalization of the domestic market has encouraged many firms to introduce improvement programmes, whose points of reference are the levels of performance considered to be internationally competitive.

Recent research and observation has confirmed that the implantation of processes leading to improvement, which will be referred to here as Quality and Productivity Programmes (QPPs), has characteristics which are specific to the nature of the goods and services, labour markets and competitive strategies found in different sectors of industry. An exhaustive account of all the differences observed cannot be presented here. Instead, an analysis will be made of certain aspects of the introduction of QPPs in metalmechanical firms and in firms operating in industries using predominantly mature technologies. The empirical basis for the analysis comes from recent field research on the introduction of QPPs in Brazil. In each of the studies, the author was directly involved in the research (SCT 1991; Ruas and Antunes 1992; Fleury and Humphrey 1992; SCT/SEBRAE 1992)

\section{QUALITY AND PRODUCTIVITY PROGRAMMES}

Generally speaking, comprehensive and lastingQPPs begin with a review of market strategy, which can often involve focusing on particular products or processes and strengthening specialization. This initial and fundamental stage in developing a QPP is of strategic importance in the process of crisis and change provoked by the current recession. Within the firm, aspects of internal management strategy are assessed - including organizational culture, human resource policies and levels of quality, produc- 
tivity and flexibility. In each case, a comparison is made with the standards achieved by international competitors.

It is evident that the effective implementation of a QPP which aims to turn the firm into an efficient and competitive organization requires comprehensive change, including both company culture (management's own attitudes towards change, the relation of workers to the aims and objectives of the firm, group activities, etc.) and operational innovations (Total Quality Control, Just-in-Time, Kanban, Statistical Process Control, etc.). ${ }^{1}$

One of the most important aspects of these changes is, without doubt, labour relations. To the extent that QPPs attribute new responsibilities and functions to workers, it is essential to create and develop a climate in which there is widespread acceptance of the firm's new objectives and aims. Studies of firms which have implanted QPPs (Fleury and Humphrey 1992, for example) have shown that various changes are made in the responsibilities attributed to workers:

- responsibility for quality control integrated with production work

- participation in the definition of norms and procedures related to quality inspection

- filling out of SPC Charts or Control Cards

- participation in groups which solve problems or seek improvements

- preparation and adjustment of equipment

- rotation of jobs

- routine maintenance.

All this requires worker involvement and cooperation. This is a complex issue because it can involve many different aspects of the firm. Generally speaking, the process is set in train by programmes of training aimed at promoting greater awareness of, sensibility to and involvement in, comprehensive change. The process is normally supported by the provision of direct and indirect benefits to workers, such as recognition of skills, training and non-monetary rewards. It is only when workers 'accept' change that it is possible to develop procedures which require them to take on new responsibilities, or even use their own initiative, as in Quality Circles or kaizen groups.

A corollary of this is that success depends on a substantial shift in prevailing management culture. Up until now, most firms in Brazil have based their organization on rigid hierarchy, centralized decision-making and the planning, execution and control of work by individual workers in narrowlydefined jobs. As a result, the major obstacles to strategies aimed at involving and mobilizing workers arise from:

a labour relations, which until recently have been marked by high levels of conflict and by instability of employment;

b the deep economic crisis which has undermined agreements on stability of employment made between workers and employers (Ruas, Antunes and Roese 1993);

c the conservatism of employers, who are reluctant to start effective negotiations with workers;

$\mathrm{d}$ the resistance, on grounds of principle, to changes in work organization and labour relations on the part of some unions.

\section{QPPS IN THE METAL-MECHANICAL SECTOR}

The metal-mechanical sector shows the highest number of firms successfully implementing QPPs. The automotive industry has played a particularly important role. The demands for improved quality, price and flexibility coming from assemblers operating in the local market and from customers in export markets have driven forward the process of change. Firm strategies are influenced by the needs of quality, price and flexibility more in the auto parts sector than any other.

Firms in the automotive industry are more inclined than any others to adopt a broad, strategic approach, in which initiatives to improve quality and productivity are put in the context of more generalized change (Ruas, Antunes and Roese 1993). It is not uncommon to find firms which make profound changes in their market and product strategies. In some cases, firms have significantly reduced the

'For brief definitions of these terms, see the Appendix to the Introduction to this Bulletin. 
variety of products they offer in the market, in a process referred to as 'focusing and specialization'. Other firms have chosen the path of product diversification. $^{2}$

The redefinition of products and markets has consequences for production. Some firms have greatly reorganized their factories, and through a strategy of focusing production, they have developed 'minifactories' and production cells. At the same time, as a result of plans to improve productivity and eliminate waste they have introduced internal JIT and production control systems such as kanban. The gains obtained in some metal-mechanical firms are impressive. A study by Lima (1989) shows substantial reductions in the space taken up by machinery and equipment, reductions in product throughput time, cuts in the number of separate items produced and increases in labour productivity. Similar results were found by the IPEA study.

In spite of these gains, QPPs have not produced satisfactory results in terms of promoting labour's involvement and participation. Labour relations, in particular, remain difficult. In part, this is because of the effects of recession (excess capacity, high levels of unemployment, falling real wages, etc.) which put strain on labour relations, and, in particular, undermine employment guarantees. In one firm, a commitment to stability of employment established in 1987 was abandoned in 1990 . According to one of the directors, 'In January 1990, it was necessary to dismiss almost 30 per cent of the workforce because of a fall in demand' (Ruas, Antunes and Roese 1992: 23). Even so, QPPs do seem to reduce turnover, except in the cases of large-scale rationalization (Fleury and Humphrey 1992: 56-57). Change has also been impeded by the inability of companies to make rapid changes to management cultures which have been historically authoritarian and conservative. Although directors and managers of various firms have reaffirmed the strategic importance of initiatives to involve and mobilize labour, in practice most firms have introduced QPPs with little or no negotiation (Ruas and Antunes 1992; Fleury and Humphrey 1992).

\footnotetext{
${ }^{2}$ Toillustrate these points, two cases can be cited. In one, a subsidiary of a transnational company making machinery assessed the loss of competitiveness it faced as a result of ta riff reductions and decided to reduce the number of models it produced from nine to four. In the other, a producer of agricultural equipment diversified into machinery for the construction industry as a result of the recession in agriculture.
}

Little has been offered to labour which does not also provide advantages to the employers. Stability of employment for a large part of the labour force also means keeping groups of workers together, which in turn is required if technological capability and improvement practices such as kaizen are to be developed. Training improves the productive capacity of employees. Participatory management helps management to establish new norms and procedures in the context of TQC.

Firms introducing QPPs normally seek to avoid any union involvement. ${ }^{3}$ A production manager at one firm which had developed a very successful QPP said in an interview that he had no interest whatsoever in negotiating with the union: 'We have a policy of anticipating the union's demands. When they are planning to make a new demand we are already offering it to our workers' (Ruas, Antunes and Roese 1992). This statement confirms the results presented by Fleury and Humphrey (1992: 53 ). The new management strategies have tried to keep the unions well distanced from the changes taking place.

This management position has encouraged unions in the metal-mechanical industry to adopt a position, which if not one of outright resistance, is at least reticent in relation to QPPs. Unions are withholding support, partly because there has been no systematic and serious debate within the labour movement on questions linked to new technology, quality programmes, participatory management and the like. It seems to be the case that the unions still lack a clear view about what workers' role in these processes of changes should be. The clearest positions on these questions in the labour movement tend to be held by individuals, in some cases by trade union leaders, and formalized institutional positions are rare.

One reason for this is simply that the process of managerial modernization is a recent phenomenon in Brazil, and there is still no clear empirical basis on which to form an opinion on the advantages and disadvantages for workers resulting from it. Recently, some unions have taken steps to seek out

${ }^{3}$ In each district (town or groups of towns) there is one union foreach category of industry (metalworkers, footwear workers, etc.). These unions have sole legal rights for representation and negotiation at district level. They have no legal right to organize at firm level or within factories. 
specialists in the field so that together they can take forward a broad-based debate on the subject.

To summarize, the QPPs implanted by firms in the metal-mechanical sector seem to be advancing well from the point of view of efficiency and organizational gains. This is in spite of difficulties in relation to worker involvement with these programmes and the relatively slow decline of traditional and conservative aspects of the prevailing management culture. ${ }^{4}$ These findings of the metal-mechanical sector could also be applied to other more advanced industries, including electronics, paper and pulp, petrochemicals, steel and banking.

\section{QUALITY AND PRODUCTIVITY IN TRADITIONAL INDUSTRIES}

Firms in industries using what can be termed traditional technologies face greater difficulties. To begin with, competition in the markets served by this type of firm is predominantly price-based, and this has a major influence on company strategy. It helps to explain, although not to justify, the policies aimed at reducing labour costs generally adopted by firms in these industries, which focus on low wages, high turnover and subcontracting to outworkers. Low costs in these sectors are generally synonymous with precarious employment. Few firms have made the link between the type of QPPs adopted in more advanced sectors and opportunities to reduce labour costs by means of increasing productivity and cutting down on defective products and rework.

A second problem which should be highlighted is the low rate of technological change and development in traditional sectors. This tends to create a managerial culture which is resistant to change and in which innovation is an infrequent event, separate from thefirm's normal activities. This gives rise to a series of factors which impede the introduction of QPPs:

- levels of investment directed towards product and process development are generally low

- firms lack human resources with the technical capacity to assimilate, adapt and implant princi-

\footnotetext{
${ }^{4}$ The director of a Brazilian conglomerate with companies in the metal-mechanical sector recounted the experience of one of the group's factories. After having organized the management and technical systems needed for change, the firm was forced to revert to traditional patterns of management because the new system had
}

ples and techniques of management developed in other sectors of industry

- technical norms, management systems and production control are poorly developed

- internal training policies and practices are almost entirely absent because of the low skill of workers in these sectors.

In addition to these difficulties with management, there are also problems with labour relations which affect the involvement and participation of workers in the aims and objectives of the companies employing them. Firstly, it should be noted that average wages in sectors such as furniture, timber, leather and footwear are the lowest in manufacturing (CEAG/IDERGS 1990). 5 Secondly, employment is unstable - 56 per cent of employees in the furniture industry had been employed for less than two years in December 1990 (SCT 1991). Thirdly, levels of education and skill are low. In the same industry, 80 per cent of the labour force had completed not more than first grade education (eight years). In the footwear industry, more than 70 per cent of labour is considered to be unskilled. Finally, few firms in either the furniture or the footwear industries have adopted policies which value the development of human resources. Few firms pay attention to skillupgrading, training, occupational structures and promotion paths. In general, and above all in smalland medium-sized firms, training is done on-the-job by the more experienced workers. This does nothing to expand the skills and knowledge available to the firm.

In the case of the furniture industry, for example, it might be assumed that raising competitiveness would involve improving workers' skills (SCT 1991). However, in the past few years, there have been unfilled places on the short courses offered by the main industry training organization, SENAI. It is said that firms have no interest in courses run in working hours, and as a result, some firms send workers to night classes. However, few workers can manage to work an eight-hour day as well as a night class, and drop-out rates for such courses are high (Ruas and Antunes 1992). ${ }^{6}$ broken down. According to the director of this company, the preparation and training of first-line supervisors and workers had not been sufficiently developed.

${ }^{5}$ The data refers to the State of Rio Grande do Sul 
These structural factors create many obstacles for the implantation of QPPs in more traditional sectors. However, given the current wave of quality awareness in Brazil, many firms in sectors such as furniture, footwear, leather and food products have tried in some form or other to introduce improvement programmes. Rather than introducing wide-ranging changes, involving market strategies, management practices and organizational culture, managements in these sectors have concentrated on introducing improved techniques of production organization and control. The most commonly observed techniques are SPC, cellular production, mini-factories and, occasionally, kanban. This approach to change is principally aimed at resolving specific problems in the production process in order to respond to new pressures for flexibility and quality. These pressures have been greatest for firms which have turned to export markets because of the crisis in the Brazilian economy.

Even within the narrow confines of production techniques and practices, the assimilation of more general principles has been limited. This limited understanding of the nature and breadth of the changes required, combined with the problems posed by management's own restricted capabilities, explains some instances of mistakes in the implementation of new management practices. Group-working in some footwear companies is a case in point. Groupworking was introduced as a replacement for conveyor belts in sewing areas. It was introduced with the aim of obtaining greater flexibility and productivity and also substantially reducing levels of workin-progress, and according to recent studies, it has achieved very satisfactory results in terms of quality of work, motivation and collaboration between workers (Ruas 1989; Piccinini 1990). However, groupworking should mean giving workers responsibility for and control over the quality of their own work. It was hoped that group-working would find an optimal trade-off between productivity and quality which would reduce the costs associated with rework and defective components and products. Paradoxically, one of the practices which has accompanied the diffusion of group-working in the footwear industry is precisely the strengthening of inspection designed to control the speed of work (Bastos and Prochnik 1991).
It seems clear that change in traditional sectors has been incremental and limited. Where more broadranging programmes for change have been introduced, they have been confined to the middle and upper layers of management and have hardly affected workers on the shop floor.

Obviously, there are exceptions. A few large firms in the footwear, leather and furniture industries have tried to change their labour relations and promote worker involvement and participation. Generally speaking, these firms have adopted policies which we have termed 'retrieving the social' in an earlier article (Ruas, Antunes and Roese 1992). This term is used because the policy is based on providing social benefits which in developed countries would normally be provided by the State. These include basic education, creches, medical insurance or dental and health services on-site, and packages of basic food items at subsidised prices. The firms are seeking involvement by providing social benefits beyond what are available to the population at large, rather than providing direct help in the form of higher wages. In this situation, skill upgrading strategies such as training, reskilling and new occupational structures are rarely found.

An example of 'retrieving the social' was seen in a large footwear company in Rio Grande do Sul, which built a centre for the care and education of workers' children. In addition, it developed some family welfare initiatives, such as health insurance, food packages, etc. The firm hoped that these measures would increase workers' commitment and involvement. In the furniture and leather industries, the same kind of welfare initiatives have also been observed.

In these firms, just as in the metal-mechanical sector, there does not appear to be any explicit resistance to change from workers on the shop floor, either now or in prospect. The development of collective resistance, even informally, among these workers is hampered by the high level of turnover, which prevents representative and stable leaders from developing in the plants. This should mean that the introduction of new work organization will not, in the short run at least, encounter resistance from workers in these sectors. In contrast, the position of unions on the

\footnotetext{
${ }^{6}$ In addition to a working week of 44-48 hours, workers can also spend long periods travelling to and from work because of the poor transport infrastructure in most Brazilian towns.
} 
issues of changes in techniques and management strategies appears to be more favourable than was seen in the metal-mechanical sector. In relation to group-working, for example, the unions' line is that 'these techniques allow workers to communicate more with each other, making work more human'. In relation to the use of modern equipment, the unions believe that it 'creates conditions which make work less arduous and more precise' (Piccinini 1991).

\section{FINAL COMMENTS}

A simplified outline of the introduction of QPPs in the metal-mechanical and traditional sectors can be drawn. As has been shown, firms in the metalmechanicalsector havedisplayed impressivechanges in terms of efficiency, productivity, quality, and reductions in costs and waste. This is not to deny that these firms have often encountered major problems, have sometimes made temporary retreats, and even confronted problems which have remained unresolvable for some time. However, the most complex problems for these programmes, and ones which are also important for their success, concern labour relations, which have until recently been characterized by their instability and precariousness. Relations with the unions have also been difficult and an obstacle to be taken into account.
In the firms studied in the traditional sectors, it has been shown that QPPs are developed with a strong bias towards techniques and practices which improve productivity. For this reason, they are quite limited in scope and restricted to certain parts of factories and firms. In addition, managements do not display a great concern with either market strategies or general management policies. With respect to labour relations and worker involvement, managements have tried to attend to the welfare of employees through the area of indirect benefits rather than exploring areas such as participation and skill upgrading.

The contrast between the metalworking and traditional industries is summarized in Table 2 . The metalworking industries adopt the global strategy and the traditional firms a more partial strategy.

A common characteristic of both sectors is the clear evidence that small firms have most difficulty in introducing QPPs. A survey carried out by the Federal government's agency for promoting small and micro enterprises, SEBRAE, showed that more than 60 per cent of small firms do not have the means to apply systematic control of production and costs (Folha de S. Paulo, 7 March, 1992). It is wellestablished that one of the fundamental bases of

Table 2: Firm Strategies for Quality and Productivity Programmes

\begin{tabular}{|c|c|c|c|}
\hline $\begin{array}{l}\text { Type of } \\
\text { Strategy }\end{array}$ & $\begin{array}{l}\text { Type of } \\
\text { Change }\end{array}$ & $\begin{array}{l}\text { Techniques and } \\
\text { Instruments }\end{array}$ & Requirements \\
\hline Global & $\begin{array}{l}\text { Cultural } \\
\text { and } \\
\text { Operative }\end{array}$ & $\begin{array}{l}\text { TQC } \\
\text { JIT } \\
\text { Kaizen } \\
\text { SPC } \\
\text { Quality Circles }\end{array}$ & $\begin{array}{l}\text { Broad Training: } \\
\text { Cultural and operative } \\
\text { Generalized benefits } \\
\text { Improvement in } \\
\text { educational standards }\end{array}$ \\
\hline Partial & $\begin{array}{l}\text { Emphasis } \\
\text { on the } \\
\text { Operative }\end{array}$ & $\begin{array}{l}\text { Kanban } \\
\text { SPC } \\
\text { Manufacturing } \\
\text { Cells }\end{array}$ & $\begin{array}{l}\text { Emphasis on operational } \\
\text { training } \\
\text { Specific benefits offered } \\
\text { to workers }\end{array}$ \\
\hline
\end{tabular}


quality programmes is systematic information. For this, predictability and routine are required. Hence the introduction of QPPs begins with an analysis of the processes being undertaken. Up to a point, this is a 'participatory application' of Taylorist motion and time study. In fact, these problems are not limited to small firms in Brazil. It is not by accident that one of the most critical periods in the introduction of TQC in Brazil is precisely the stage where processes are brought under control and norms established. ${ }^{7}$
Finally, it should be noted that QPPs in Brazil pay particular attention to the question of cost, or reduction of waste. For a long period firms faced growth in demand, which made their chief concern one of increasing productive capacity. Little was done to rationalize the use of resources. In a very different market climate, quality programmes have made their first priority the reduction of waste caused by scrap and rework.
${ }^{7}$ The concern shown by Brazilian firms with the question of establishing norms for production and management systems and bringing them under control became very clear in a meeting promoted by the body representing JUSE (the Japanese Union of Scientists and Engineers) in September 1992. On this occasion, more than 700 directors, managers and engineers, representing approximatley 250 mostly large- and medium-sized firms attended a meeting in order to learn about and discuss exemplary cases of normalization of products and processes in five local firms.

\section{REFERENCES}

Bastos, C. and Prochnik, V., 1991, 'Política Tecnológica e Industrial para o Setor de Calçados', Preliminary Research Report, Rio de Janeiro

CEAG/IDERGS, 1990, Censo Industrial, Rio Grande do Sul, Porto Alegre: Instituto de Desenvolvimento Empresarial do Rio Grande do Sul

Fleury, A. and Humphrey, J., 1992, 'Recursos Humanos e a Difusão e Adaptação de Novos Métodos de Qualidade no Brasil' Working Paper, Brasília: IPEA, (a revised version will be forthcoming as an IDS Discussion Paper in 1993)

Lima, I., 1989, 'Análise das Consequências da Utilização das Filosofias e Técnicas Japonesas de Gestão da Produção sobre o Rendimento das Empresas', Unpublished MA dissertation, Federal University of Rio Grande do Sul

Piccinini, V., 1990, 'L'ind ustrie de la Chaussure Brésilienne Face aux Mutations Internationales: Stratégies et Politique du Personnel des Entreprises de la Région de "Vales dos Sinos"', Unpublished PhD thesis, University of Grenoble
Ruas, R., 1989, 'Difusão de novas paradigmas da produção ind ustrial: convergência e especifidades em dois segmentos industriais', Anais, Padrões Tecnológicos e Políticas de Gestão: Comparações Internacionais, University of São Paulo

Ruas, R. and Antunes, J., 1992, 'Novas formas de organização e estratégias de gestãao de trabalho em indústrias tradicionais', in ANPOCS, Ciências Sociais Hoje, Rio de Janeiro: Fundo

Ruas, R., Antunes, J. and Roese, M., 1993, 'Organisation de la production, "Modèle Japonais" et gestion de la force de travail au Brésil', in H. Hirata (ed.), Autour du 'Modèle' Japonais, Paris: Harmattan

SCT (Science and Tecnology Secretariat, Rio Grand do Sul), 1991, 'Tecnologia e competividade: análise e perspectivas da ind ústria moveleira do RS', Porto Alegre: SCT

SCT/SEBRAE - RS, 1992, 'Tecnologia e competitividade: análise e perspectivas da indústria calçadista do $\mathrm{RS}^{\prime}$, Porto Alegre:SCT and Serviço de Apoioà Pequena eMicroempresa 